\title{
The role of literary festival attendance in generating attendees' health and well-being
}

\section{Introduction}

The Third United Nations Sustainable Development Goal is to ensure 'healthy lives and promoting well-being at all ages' (UN, 2020a). The Goal includes mental and physical health support. As such, 'ensuring healthy lives and promoting well-being is important to building prosperous societies' (UN, 2020b, p.1). The Sustainable Development Goals Report (2020, p.3) also says that nowadays all countries, even the developed ones, 'are struggling to cope with the health, social and economic fallout of the pandemic'. Researching ways to promote mental and physical well-being is therefore crucial.

There is a wealth of literature about the benefits of arts participation on people's wellbeing and health. Involvement in different types of art is known to be beneficial for people's mental health. Studies on art therapy and well-being are many. Examples include dancing (Weinberg and Joseph, 2017), singing (Daykin et al., 2018), and writing retreats (Stevenson, 2020). Several studies also claimed that viewing art in museums or art galleries can be therapeutic and improve well-being (Chatterjee et al., 2018: Flatt et al., 2015). For instance, Binnie (2010) observed that visitors perceive a reduction of anxiety after visiting art museums.

There is also good evidence that leisure practices have a role in promoting subjective well-being and improving quality-of-life. For instance, Brajša-Žganec et al. (2011, p. 81) observed that while participating in leisure activities 'people build social relationships, feel positive emotions, acquire additional skills and knowledge, and therefore improve their quality of life'. Similarly, Mirehie and Gibson (2020) argued that participation in snow-sports enhances physical and psychological well-being in women. Several studies also claimed that 
leisure practices such as creative travel experiences (Huang et al., 2019), and tourism more generally (Nawijn and Filep, 2016; Vada et al., 2020), promote well-being.

Here the question is whether festivals are occasions to promote people's health and well-being. Understanding this is crucial in todays' society that faces mental and physical health issues due to Covid-19 lockdown restrictions (Garcia-Esquinas et al., 2021; The Sustainable Development Goals Report, 2020). Academic deliberations have started to understand the role of events in generating well-being. For example, Brajša-Žganec et al. (2011) claimed that attending cultural events can significantly contribute to people's wellbeing. However, they only considered exhibitions, theatre, and concerts. Wood et al. (2018) investigated the role of participatory arts events in promoting well-being for the over 70s. They argued that arts event attendance reduces the risk of loneliness and isolation, and increases selfesteem and self-worth. However, the role of festivals in promoting well-being is still underexplored. As Brownett (2018, p. 71) claimed, 'very little research exists about the contribution of arts festivals for community health and wellbeing'. Likewise, Kitchen and Filep (2019, p. 67) argued that 'there is a need for a better understanding of how event participation is valued by attendees, especially in terms of their psychological wellbeing'.

To date, scholars have mainly focused on the social or psychological well-being outcomes of festivals (Jepson and Stadler, 2017; Wood et al., 2018). This suggests that other dimensions of the well-being outcomes, such as physical and spiritual, need to be further understood. A more comprehensive study that captures all the possible dimensions of wellbeing promoted by festivals is needed. As Linton et al. $(2016$, p.1) argued, scholars from different disciplines are trying to measure well-being, 'but it is not always clear what they are measuring'. Thus, it is first important to understand all the well-being dimensions in order to fully conceptualise it. To fill this research gap, this paper aims to investigate the well-being dimensions promoted by festival attendance, and the factors that can generate attendees' overall 
well-being. The results of this exploratory investigation have the potential to guide further research by creating a more comprehensive understanding of how well-being is generated by festival attendance.

\section{Theoretical background}

\section{Defining well-being}

There is a wealth of literature that explores well-being in various disciplines, from health, to leisure, and art. One of the first philosophers that conceptualised well-being was Aristotle, who identified two components: hedonic and eudaimonic well-being. Hedonic well-being is happiness and life satisfaction, while eudaimonic well-being is the 'actualization of the human potential' (Baselmans and Bartels, 2018, p. 1). More recently, the concept of hedonic wellbeing has shifted towards Diener's (1984) concept of subjective well-being (Baselmans and Bartels, 2018). Likewise, eudaimonic well-being has been operationalised using the concept of psychological well-being (Baselmans and Bartels, 2018). However, well-being also refers to a more physical state. For instance, the World Health Organisation included the concept of wellbeing in its definition of health, as 'a state of complete physical, mental and social well-being and not merely the absence of disease or infirmity' (WHO, 2020).

Nevertheless, to date, there is not a uniform agreement on how to best conceptualise well-being (Linton et al., 2016). For instance, Nieboer et al. (2005) identified the social production function theory's dimensions of well-being: affection, behavioural confirmation, status, comfort, and stimulation. A widely used construct is Seligman's (2011) PERMA model that identifies five domains of well-being: positive emotions, engagement, relationships, meaning, and accomplishment. Instead, according to Lindert et al. (2015, p. 737), 'wellbeing is a theoretical construct which encompasses emotional (affects/feelings), psychological 
(positive functioning), social (relations with others) and spiritual (sense of purpose in life) [dimensions]'. One of the latest and more comprehensive analyses of the dimensions of wellbeing was conducted by Linton et al. (2016). They reviewed 99 measurements and 196 dimensions of well-being and identified six main domains: social wellbeing, mental wellbeing, spiritual well-being, physical well-being, activities and functioning, and personal circumstances.

Nevertheless, there is still ambiguity surrounding the ways well-being is conceptualised and measured. This paper's interpretation of well-being is similar to Linton et al. (2016): it can include, at least in festival contexts, mental, physical, social, emotional, and spiritual dimensions. However, the paper does not attempt to provide a new measurement tool or definition. It is hoped that this exploratory study is the basis to further the understanding of the well-being outcomes associated with festivals.

\section{Festivals and well-being}

A few scholars started to explore the connections between festival attendance and the creation of individual well-being. For instance, Heldt (2014) measured how music festival participation impacts subjective well-being and happiness. Similarly, Saragih and Amelia (2020) used the concept of hedonia to conceptualise hedonic well-being at music festivals.

Studies focused on different domains of well-being, one of which is social well-being. For instance, Arcodia and Whitford (2006) claimed that festival attendance can develop social capital, in terms of, for example, social cohesiveness. By using the concept of social capital, Brownett (2018) also observed that arts festivals produce social well-being. Similarly, Wood et al. (2018), while analysing the social benefits of art events for older adults, claimed that more studies should explore the role of events in decreasing isolation and loneliness. They also 
argued that, while several scholars investigated personal benefits of music festivals, more studies are needed into other forms of art, such as literature and writing. This paper answers this call by investigating one literary festival.

Mental well-being outcomes have also been an object of study. For example, Quinn et al. (2011) explored the well-being outcome of arts and film festival attendance and claimed that arts festivals should be integrated in national programmes to promote mental health and well-being, like generating positive attitudes, inspiration, and fostering capabilities. Rossetti and Quinn (2021) claimed that at literary festivals people can acquire cultural capital. Similarly, Ballantyne et al. (2014) observed that music festivals promote psychological well-being in terms of acquiring skills. Nevertheless, only a few studies explored how festivals promote spiritual well-being and spiritual engagement (Mellor et al., 2012; Soulodre, 2019). For example, Mackay (2014) observed that art-making at festivals can create a spiritual experience and allow women to connect to a divine energy.

Likewise, only a few scholars investigated the role of festivals and events in fostering physical well-being. For instance, Stevinson and Hickson (2019, p. 807) observed that regular attendance at a weekly running event created 'significant changes in weight, fitness, and wellbeing' in participants. Similarly, Dougan Bowtell (2012) noticed that attendees can feel body awareness and sense of well-being by attending yoga festivals. Thus, festivals might impact attendees' physical well-being, but more research is needed to better understand this possible outcome. Related to the UN Sustainable Development Goals, the Peace Relay programme focuses on physical health. It aims at improving the global health movement for all. The programme was presented at the Olympic Games in 2014 and is now revealing its positive results (Relay of peace, 2021). 
All the above means that, despite a growing body of literature on well-being benefits associated with festivals, further research on this under-explored topic is necessary (Brownett, 2018). This gap is supported by others scholars that claim that 'there is clearly a research need to investigate the processes concerned with participatory arts events with a view to understanding the psychosocial or emotional well-being of the cultural self and the benefits arts and cultural events can provide to older people' (Wood et al., 2018, p. 1096), and adults more generally. Analysing literary festivals, Ommundsen (2009, p.21) argued that festival consumption is an 'active involvement - physical, emotional, intellectual and social'. Nevertheless, to date, there is not a comprehensive research framework on the well-being outcome of festival attendance that incorporates all these dimensions. While scholars started to understand 'subjective benefits of attending festivals, the reporting of positive health outcomes remains underdeveloped' (Wood, 2019, p. 323).

Moreover, only a few studies examined the festival factors that generate attendees' well-being. For instance Tan et al. (2020) argued that, in music festivals, the programme, food, information services, and festival value are the main elements that influence subjective wellbeing. However, more studies are needed to fully understand the factors that influence attendees' health and well-being.

Festivals have been described as 'transformative experiences' (Brownett, 2018, p. 9), but how do they transform attendees' health and overall well-being? Understanding this is especially important nowadays, as the Covid-19 pandemic has caused a reduction of physical activity, social interaction and mental health issues (Garcia-Esquinas et al., 2021; JiménezPavón et al., 2020). This paper answers these shortcomings and the contribution is twofold. Firstly, it explores what well-being dimensions festival attendance has the potential to generate. Secondly, it investigates what factors promote attendees' health and well-being. 


\section{Methodology}

This exploratory study draws on a wider research project into participants' cultural outcomes associated with festival attendance. The study presented here adopts an inductive and interpretivist approach. The epistemological assumption is intersubjective and the ontological assumption is that multiple realities exist (Yin, 2016). The methodology involves a nonprobability sample and, given the exploratory nature of the research, it includes one case study: an Irish literary festival.

Literary festivals are cultural festivals dedicated to books, writers, and literature more generally. Their main aims are to foster reading/writing and promote books and authors (Rossetti \& Quinn, 2019; Weber, 2018). They have been described as cultural events that 'provide intellectual stimulation, a sense of intimate community, and opportunities for social and ethical reflection' (Driscoll, 2014, p. 192). Johanson and Freeman (2021, p. 314), for example, argued that literary festival attendance can foster social networking and 'a sense of cultural community'. The case study is an Irish literary festival that in 2017 featured more than one hundred events, some of which were writing workshops and literary awards. The events were located in 33 venues around the town, including the square and the local museum. Permission to carry out the study was obtained from the researcher's University, so the study conformed to the ethical standard required.

This paper proposes a qualitative design with two phases of data collection. Phase 1 included on-site observations and 45 semi-structured interviews during the festival. The interviews involved a combination of purposive and snowball sampling (Yin, 2016). The questions covered how participants were consuming the festival. They included, for example: 
'Are you enjoying the festival?'; 'What does the festival mean to you?'; 'Are you alone or with someone?'; 'Do you have the impression that you have learned something?'.

The observations were conducted using Descombe's (2010, p. 207) approach of 'normal setting', so only the festival organisers were aware of the research being conducted. The observations followed Taylor et al.'s (2016) and Holloway et al.'s (2010) suggestions to record field notes, and were useful to collect data on attendees' emotions and behaviours.

Phase 2 involved 17 in-depth, follow-up, semi-structured interviews after the festival. The sample of the follow-up interviews was purposive and interviewees were recruited at the festival during the on-site interviews. The follow-up interviews were collected 2-4 weeks after the festival, to allow respondents to finish their festival experience and become aware of possible personal benefits. The interviews included questions, such as: 'What do you remember of the festival?'; 'During the days of the festival did you feel part of a community?'; 'Were you glad you went? Why?'; 'Did you enjoy it? Why?'; 'What did you get out of it?'.

The background of the follow-up (FU) interviewees reflected the background of the onsite (OS) interviewees. All the respondents were adults over 18 years, mainly women (62\% OS; $65 \% \mathrm{FU})$, aged in their $50 \mathrm{~s}(24 \% \mathrm{OS} ; 35 \% \mathrm{FU})$ or $60 \mathrm{~s}$ (29\% OS; $24 \% \mathrm{FU})$, domestic tourists (82\% OS; 76\% FU), and repeat visitors (64\% OS; 65\% FU). Most of them were attending the festival alone ( $40 \% \mathrm{OS} ; 35 \% \mathrm{FU})$ or in a group (38\% OS; $35 \% \mathrm{FU})$. They mainly spent all the 5 days at the festival (29\% OS; $41 \% \mathrm{FU})$ and attended from 2 to 5 events $(56 \%$ OS; $41 \%$ FU). Fantasy names will be used to present the findings.

All the interviews were transcribed verbatim and validity was strengthened with triangulation (Yin, 2016). Braun and Clarke's (2006) thematic analysis was used to analyse the data and create a conceptual framework on how festival attendance promotes attendees' overall well-being. Like Ommundsen (2009), this paper considers literary festival attendance as an 
emotional, physical, intellectual and social experience, and data revealed that the well-being dimensions were related to these domains. Moreover, results also included a fifth dimension: a spiritual dimension. Thus, five key themes were identified: social well-being; mental wellbeing; emotional well-being; spiritual well-being; and physical well-being. For each theme, several codes were created to identify the factors that generated well-being, such as, the social environment or the festival programme. Even if this is only one exploratory case-study, and results cannot be generalizable, the findings can be used to guide further investigations on festivals and well-being.

\section{Findings}

Findings showed that the festival promoted attendees' well-being and health. Results revealed that festival attendance can have the potential to generate five interconnected well-being dimensions (social, mental, emotional, spiritual, and physical). Data also showed that attendees' well-being benefits were generated by the interaction of five factors: festival programme, social environment, place, weather conditions, and attendees' background.

\section{The need for social interaction}

Observational data showed that participants were chatting, laughing, and socialising in and around festival venues as well as during and between festival events. The on-site interviews revealed that more than half $(58 \%)$ of the respondents were attending the festival with at least another person, mainly friends or spouse/partners. Thus, the festival was an occasion to maintain and reinforce existing social connections. While for those who were attending alone ( $40 \% \mathrm{OS} ; 35 \% \mathrm{FU})$, the festival was an occasion to create new relationships and improve social networking. 
A more in-depth analysis revealed how the festival promoted social well-being in participants. For instance, 'people were so friendly', said Missy. Rita also noticed that 'you may just get chatting with someone in a café and before you know they told you their stories or you told them your story'. According to Rita, what created these social occasions was the union of the festive atmosphere and the 'special place' of the town. 'I like the town, I like the size of it, it's nice and compact, I love all the positivity around it', she explained. The features of the town allowed social networking, which, in turn, generated positive feelings. Similarly, Dennis argued that the little size of the town and the good weather allowed people to meet after some events, network, chat, and exchange ideas. He said that after attending a writing workshop, 'it was interesting... drinking tea outside in the square and there would be people walking [that] you would recognise them from the [writing] course, because the town is so small... there's the thing, you just talk to random people... and [you get] different perspectives on things you wouldn't necessarily thought'.

Moreover, others claimed that the festival programme improved their social well-being. For instance, Missy took part in a writing competition and won the first prize of 1,000 euro. After the festival, she used the money to increase her social relationships: 'I have two grandchildren in America that I have never seen so I booked tickets for America with the money I won'.

All the above means that social well-being was perceived as a generation of social interactions, relationships, and loneliness reduction. It was promoted by the social environment, the festival programme, the place (the size of the town), and weather conditions (Figure 1).

A sense of being mentally well 
Data showed that the festival had a role in enhancing mental well-being. The experience was described as intellectually satisfying. For instance, Norah explained that the festival experience was intellectually satisfying because it answered her curiosity and needs: 'it satisfied me to hear things I want to hear, and read things I want to read and see things I want to look at'. Likewise, Maoreen enjoyed the festival because it was a 'mentally stimulation... just something I can reflect on, in a later stage'.

Moreover, some interviewees were feeling psychologically well because the events they attended augmented their self-esteem and sense of 'feel more please' (Missy) with themselves. For example, Dennis observed, one event was a 'good opportunity [for attendees] to express themselves and becoming confident in reading [in front of a public]'. Similarly, Ashlyn, claimed that after the festival she has been 'writing more' because the festival gave her 'probably a little bit of confidence to think, oh my God, I could write myself'. For some, the social environment of the festival experience promoted a creative feeling and psychological well-being. As Simon, a writer and domestic tourist, argued, being at the festival creates a feeling of being 'more connected to my fellow writers so that gives you a positive self-esteem'. Thus, this means that sometimes the mental and social well-being dimensions were interconnected.

Additionally, Cassie explained that she enjoyed the atmosphere because she felt safe: ‘there's no fear here, you know. When you go to some festivals, you are afraid, you get stock with a bottle or that rough element. There was none of that here. It was very relaxed'. This means that the festival atmosphere and the social environment generated a positive feeling of safety and psychological well-being. 
All the above means that that mental well-being outcome was perceived as intellectual inspiration, self-esteem augmentation, and feeling of safety. It was promoted by the social environment, the festival programme, the town, and attendees' background (Figure 1).

\section{An enjoyable moment}

Respondents said that the festival made them feel happy. As Bryan argued, 'it was a happy occasion... a pleasurable event to attend'. Marcie explained this feeling saying that the festival 'makes me happy, you have enjoyed it, you come away with a smile on your face'. Sometimes, happiness was related to the social element of the experience. For instance, Meghan observed that 'just the happiness of that Thursday night... we started at $1 \mathrm{pm}$ in one pub for 3 -minute poetry and nobody left, nobody disturbed... and we chatted... it was just a lovely evening out'. Cassie also explained that it was the festival atmosphere to bring happiness: the festival 'makes you happy... when you are in an atmosphere like this, lovely'. Evan explained that it was a 'positive experience' because 'it was getting... away from everything and being amongst a group of creative artists people... and just being surrounded by that positive energy'.

During the on-site interviews, the respondents needed to choose three adjectives to describe their experience at the festival, and they mainly chose Interesting, Fun, Friendly, and Entertaining. This suggests that they perceived an emotional positive feeling. The observations also revealed that attendees were having fun while chatting, drinking, listening and watching the performers. People were smiling and laughing. As Simon argued, at the festival 'you are laughing... there's plenty of jokes being shared'. This means that the emotional and social well-being dimensions were often linked and influenced each other.

Moreover, the attendees' origin shaped their emotional well-being outcome. For tourists, attending a literary festival can coincide with a relaxing holiday that breaks the routine. 
The festival was perceived as an enjoyable 'day away from work... good to chill out' (Jimmy). For instance, Ashlyn, a domestic tourist, said that 'it was relaxing... I had projects at work so it was nice to switch off from that'. They perceived therefore feelings of being well, in terms of relaxation, discovery, and enjoyment. Norah explained that this is because 'going to a festival is like going to a holiday for two or three days'.

All the above means that that emotional well-being outcome was perceived as happiness, fun, and relaxation. It was promoted by the social environment like networking, the festival programme, and attendees' background, such as their origin (Figure 1).

\section{An experience good for the soul}

Several respondents perceived a spiritual well-being outcome. As Jimmy said, 'I come more alive' around 'literature or people connected to literature'. Thus, for some, the festival was an occasion to engage with literature and socialise with people who shared the same passion. This enhanced a sense of spiritual well-being of being energised. Jimmy explained that '[after the festival], you go home and you feel nourished... I feel fulfilled, nourished, to listen to all the works'. Similarly, Maggie observed that the writing workshop she attended 'was quite a soul experience as well as being a literary experience'. According to her, it was because the workshop was 'harmonious towards people... [the teacher] was talking about memoir writing... [and] a lot of people were angry and they wanted to write the truth of what other people did to them... but [the teacher] rather encouraged people to try to approach memoir writing in... a storytelling mode, that it's not just to get out your anger'. Thus, the festival programme, the atmosphere of the event, and the teacher's approach created a peaceful feeling for Maggie. 
Norah also said that the festival 'is just something from my soul, for my spiritual self, rather than my physical self, and I like to go for that reason'. When asked to explain what she meant, she emphasised the social element of the festival experience: 'I enjoy going out for meals and our teas and chatting to people and sitting in the bar... everything that surrounds it'. As such, for some, the festival was a spiritual experience because it 'was very pleasant... enjoyable, [with] friendly people, [and] events for entertainment' (April). It was 'uplifting... personal enlightenment' (Molly). Here it is possible to see how, for some, the spiritual wellbeing dimension was connected with the social and emotional well-being dimensions.

Besides the social environment and the festival programme, the place was another factor that promoted spiritual well-being. Some respondents had a personal attachment to the town. For them, attending the festival generated a spiritual outcome, in terms of remembering their own early life, or a family member who passed away. Rita, who moved to another county when was only 6 months old, said that going to the festival every year is a way of remembering her past and feeling good: 'I feel like I'm going home', she said. Likewise, Laura, who lives abroad, explained that her parents were originally from the Irish town, and she was attending the festival 'because of my roots, my family'. Last time she visited the town was 'a lot of years ago' and the festival 'made me realise that for all these years I have been to this spiritual path... I just feel very comfortable here, very welcoming'. Thus, the festival experience made her feel welcome and spiritually connected to her family.

All the above means that that spiritual well-being outcome was perceived as a feeling of being energised, soul experience, nourishment, and spiritual connection to family members. It was promoted by the social environment, the festival programme (events and speakers), the place, and attendees' background such as personal attachment to the town (Figure 1). 


\section{A healthy event}

The findings also revealed how being at the festival shaped some elements of attendees' physical well-being. The weather was good for the five days of the festival and observational data showed that people were walking around the town, moving around the festival venues, and along the local river. The festival was, therefore, an occasion to increase physical movement. For instance, Dennis enjoyed 'the activities around the town and the weather helped a lot, because it was good'. Thus, the festival programme and the weather promoted physical well-being. Maggie said that she 'walked around because it's a great walking area and I chatted to young women, they were just sit down having some lunch because it was a lovely sunny day and they told me about the walks all around and where to go, so I had a walk around the river'. Thus, the social networking, weather, and natural local heritage played a role in encouraging physical movement.

Moreover, Ashlyn, a domestic tourist, claimed that going to the festival is a 'healthy kind of thing to do'. She explained that 'when you go on holiday, you normally spend your hours drinking at night, but I was driving... and reading in my free time... so it was a proper nice holiday'. Norah also observed that the festival 'is good for my heart'. She explained this by arguing that going to the festival is a break from the daily routine full of 'problems', so saying 'I'm going to [the festival] for five days, it's good for the heart' because it is perceived as a relaxing holiday.

All the above means that physical well-being was perceived as physical movement, sun exposure, relaxation, and alcohol reduction/avoidance. It was promoted by the festival programme, the social environment (such as social networking), the place (natural heritage), and weather conditions (Figure 1). 


\section{Discussion}

This paper presents a new conceptual model of participants' overall well-being generated by festival attendance. This model has been created on evidence from one festival: the case-study. This answers the call for more research on health and well-being benefits associated with festivals (Brownett, 2018; Wood, 2019). While this is only one exploratory case-study, and results cannot be generalizable, the observations and interviews were able to create a model that shows that attendees' well-being outcomes can encompass five interconnected dimensions: social, emotional, spiritual, mental, and physical (Figure 1). The paper also argues that five factors have the potential to generate attendees' health and well-being: festival programme, social environment, place, weather conditions, and attendees' background (Figure 1).

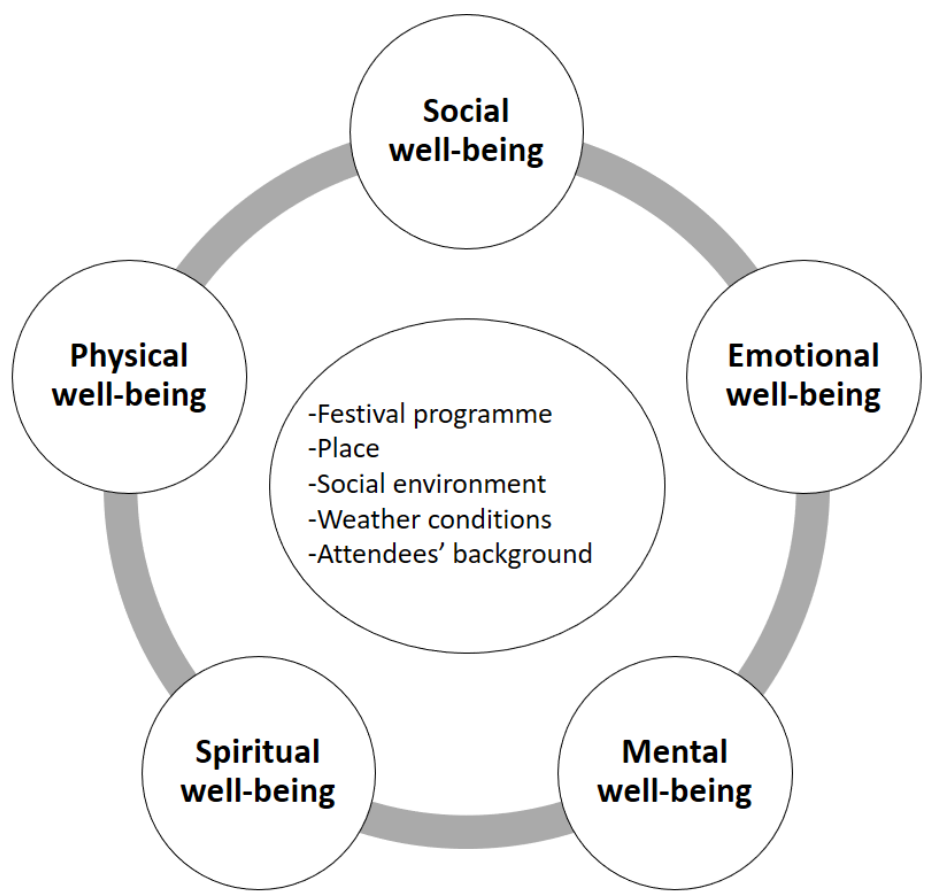

Figure 1. Conceptual model of how literary festival attendance can generate attendees' health and well-being 
There is reason to believe that festivals can be 'transformative experiences' that improve attendees' health and well-being (Brownett, 2018, p. 9). Firstly, evidence shows that through festival attendance people can build and reinforce social relationships. Thus, this paper agrees with Arcodia and Whitford (2006), Brajša-Žganec et al. (2011), and Brownett (2018) in saying that leisure activities, like festivals, promote social well-being and encourage social connections. While Wood et al. (2018) argued that adults over 70s perceive a reduction of loneliness and isolation thanks to festival attendance, this paper suggests that festivals might foster social integration and, in turn, reduce loneliness for all adults over 18 years, and not just the over 70s. Festivals are arenas for people to meet, network, chat, laugh, and have fun. This confirms Lindert et al.'s (2015) views that one of the main dimensions of well-being generated by participation in leisure activities is social well-being. It is also in line with the well-being domain named Relationships of Seligman's (2011) PERMA model. Moreover, this study goes a step further in arguing that the main factors that could foster social well-being at festivals are: the social environment, the festival programme, the place (such as the size of the town), and weather conditions. All this suggests that the festival industry might have the potential to achieve the Third UN Sustainable Development Goal that focuses on promoting good health and well-being, as well as the Sixteenth Goal on fostering inclusive societies (UN, 2020a). As the Global Sustainable Development Report (2019) claims: 'for sustainable development, the greatest asset is people. They need to be empowered and engaged in community life to enjoy a high level of satisfaction with life and to age in dignity and good health'. Thus, the ways how people meet and interact at festivals might generate social well-being and contribute to achieve the Third UN Sustainable Development Goal.

Secondly, results support Quinn et al.'s (2009), Ballantyne et al.'s (2014), and Rossetti and Quinn's (2021) views that festivals can promote mental and psychological well-being. Results show that literary festivals can be occasions where participants perceive a sense of 
being intellectually well. This is linked to the Fourth UN Sustainable Development Goal that focuses on promoting quality education to improve people's lives (UN, 2020a). Findings reveal that the festival also promoted positive psychological feelings, like feeling of safety. Moreover, attendance in some types of events generated self-esteem. This recalls the eudaimonic wellbeing in terms of 'actualization of the human potential' (Baselmans and Bartels, 2018, p. 1) and the well-being domain of Accomplishment in Seligman's (2011) PERMA model. Results also reveal that the festival programme and atmosphere can generate the mental and psychological well-being outcome. This suggests that there is scope for festival directors to take actions and increment opportunities to foster well-being in participants.

Thirdly, just like Seligman (2011), who argued that one of the well-being domains in the PERMA model is Positive Emotions, there is reason to believe that festival attendance can generate positive emotions like happiness and relaxation. Thus, this paper agrees with the view that festivals can promote happiness in participants (Heldt, 2014; Lindert et al., 2015). Findings show that people were laughing and having fun while engaging in different activities. The feeling of being well and happy during the festival recalls Aristotle's hedonic well-being and hedonia (Baselmans and Bartels, 2018; Saragih and Amelia, 2020). Moreover, results show that people were relaxed. Particularly, for tourists, festivals can be occasions to relax and escape daily problems. This supports the view that travel experiences, as festival tourism, impact on people's well-being (Huang et al., 2019; Vada et al., 2020). Thus, while Binnie (2010) argued that visiting art museums can reduce anxiety, this paper suggests that festival attendance might also promote relaxation and reduce anxiety.

Additionally, data show that, similarly to art intervention (Chatterjee et al., 2018; Flatt et al., 2015), festival attendance can also generate spiritual benefits and holistic well-being. Thus, this paper agrees with Lindert et al. (2015) in arguing that well-being is a theoretical construct which encompasses a spiritual dimension. The findings show that attendees felt 
uplifted, fulfilled, nourished, and argued that the experience was something 'for my soul, for my spiritual self' (Norah). Data support previous studies in claiming that festivals can promote spiritual engagement and well-being (Mackay, 2014; Mellor et al., 2012; Soulodre, 2019). Moreover, there is reason to believe that the social environment, the festival programme, the place, and attendees' background can generate spiritual well-being. For instance, some attendees had a personal attachment to the town and for them the act of being at the festival was a spiritual and emotional experience.

Furthermore, this paper supports the view that attendance in events and festivals impact participants' physical well-being (Mirehie and Gibson, 2020; Stevinson and Hickson, 2019). Results show that physical well-being was improved in terms of physical movement like walking, absence or reduction of alcohol intake, and sun exposure. So, this study claims that festivals could be occasions to improve attendees' physical well-being by, for example, fostering movement, creating relaxation, and a healthy lifestyle. Just like the Relay at peace programme (2021) promotes 'an interactive form of participation of the population in a health program', this paper argues that post-pandemic attendance at festivals could also benefit people's physical health. Moreover, the main factors that seem to generate attendees' physical well-being are the festival programme, the social environment, the place, and weather conditions. So, while Jiménez-Pavón et al. (2020) argued that physical exercise can serve as therapy to improve mental and physical health after COVID-19 quarantine, this paper claims that festival attendance could help as well.

All the above means that festival attendees might experience multiple well-being outcomes simultaneously. Also, there is reason to believe that the well-being dimensions 
generated by festival attendance are interconnected and influence each other. This suggests that in order to fully understand the value of festivals in generating attendees' health and well-being all the dimensions promoted by attendance should be taken into account. This paper presents an exploratory model that captures several possible well-being outcomes and opens up opportunities for more comprehensive research on festivals and well-being.

Moreover, similarly to Ballantyne et al. (2014) and Tan et al. (2020) who analysed the determinants that generate well-being for music festivals attendees, this case study shows that attendees' well-being benefits were promoted by the combination of five factors: festival programme, social environment, place, weather conditions, and attendees' background. Thus, evidence suggests that the role of festivals in generating well-being is extremely complex and more research is needed to better understand how attendance generates audiences' overall wellbeing.

\section{Conclusions}

This paper explores how literary festival attendance contributes to the audience's health and well-being. Even if it includes only one case-study, this paper can serve as exploratory research to better understand how festivals can achieve the Third UN Goal of fostering 'healthy lives and promoting well-being at all ages' (UN, 2020a). The value of the paper is twofold. Firstly, it furthers the understanding of the well-being dimensions promoted by festival attendance. While previous research explored some well-being outcomes of festival attendance, like social well-being, there is a need to further explore how festivals generate attendees' overall wellbeing and health. The paper proposes a new conceptual model that shows that festival attendance has the potential to generate five interconnected well-being dimensions: social, emotional, spiritual, mental, and physical. Secondly, the model identifies the five factors that 
can generate attendees' health and well-being: festival programme, social environment, place, weather conditions, and attendees' background.

Additionally, this paper reveals that the well-being dimensions generated by festival attendance are often linked and influence each other. For instance, social well-being can be connected to mental well-being, and emotional well-being to spiritual well-being. All this reveals the complexity of festival experiences and suggests that in order to capture attendees' overall well-being outcomes, all the dimensions should be considered. As an interviewee explained, at the festival 'you are laughing, you are thinking, you are making new connections... there's plenty of jokes being shared, plenty of thoughtful moments... it's a microcosm... it's intense and it's good' (Simon).

Practical implications are also present, considering that the Covid-19 pandemic has modified people's physical activity, social interactions, and mental health (Garcia-Esquinas et al., 2021; Jiménez-Pavón et al. 2020). The paper reveals that festivals might contribute to improving people's health and well-being. In a post-pandemic scenario, festival directors could take actions to implement programmes and venues to better promote health and well-being in the attendees. Festival managers can have a role in providing occasions for people to augment their self-esteem, feel happy, engage with their spiritual self, and improve their physical wellbeing.

This research includes only one exploratory case study that looks into how a festival promotes attendees' overall well-being. However, there are opportunities to test this model in other studies. It is hoped that the new conceptual model will be used to guide further research on festivals and well-being. Thus, this paper answers the call for more studies on how festivals could promote individuals' well-being (Brownett, 2018; Kitchen and Filep, 2019), and is in line with the Third United Nations Sustainable Development Goal: to explore opportunities to 
promote health and well-being at all ages. Since this paper uses a literary festival as a case study, it also answers Wood et al.'s (2018) call for more studies on well-being at events that include literature and writing.

The model suggested here can help to better understand the full potential of festivals in promoting attendees' overall well-being, considering all the dimensions. Future research should involve multiple cases and different types of festivals, like food and sport festivals. Further studies can also include festivals from different countries. The model should also be tested for specific age groups. Moreover, future research should better explore the possible role of festivals as arenas for alternative health and social recovery programmes. Festival involvement in public health is under-researched and needs further investigation. A possible future study can focus on festivals on prescriptions. More studies to further comprehend whether and how festival attendance can be beneficial for audiences with mental or physical disabilities is needed.

\section{Research funding}

This paper draws on Dr Rossetti's PhD thesis (2020), which was was funded by the Technological University Dublin's Fiosraigh PhD Scholarship.

\section{Acknowledgments:}

This paper draws on Dr Rossetti's PhD thesis (2020), which was funded by the Technological University Dublin's Fiosraigh PhD Scholarship. Dr Rossetti would like to express her sincere gratitude to her supervisor Dr. Bernadette Quinn for the encouragement and support. Dr Rossetti also thanks Technological University Dublin that funded this research, and the editor and the reviewers for their comments.

\section{References}


Arcodia, C. and Whitford, M. (2007), "Festival attendance and the development of social capital”, Journal of convention \& event tourism, Vol. 8, No. 2, pp. 1-18.

Ballantyne, J., Ballantyne, R. and Packer, J. (2014), "Designing and managing music festival experiences to enhance attendees' psychological and social benefits", Musicae Scientiae, Vol. 18 No. 1, pp. 65-83.

Baselmans, B.M. and Bartels, M. (2018), “A genetic perspective on the relationship between eudaimonic-and hedonic well-being”, Scientific reports, Vol. 8 No. 1, pp.1-10.

Binnie, J. (2010), "Does viewing art in the museum reduce anxiety and improve wellbeing?" Museums \& Social Issues, Vol. 5 No. 2, pp.191-201.

Brajša-Žganec, A., Merkaš, M. and Šverko, I. (2011), "Quality of life and leisure activities: How do leisure activities contribute to subjective well-being?" Social Indicators Research, Vol. 102 No. 1, pp.81-91.

Braun, V. and Clarke, V. (2006), "Using thematic analysis in psychology", Qualitative research in psychology, Vol. 3 No. 2, pp. 77-101.

Brownett, T. (2018), "Social capital and participation: The role of community arts festivals for generating well-being”, Journal of Applied Arts \& Health, Vol. 9 No. 1, pp.71-84.

Brownett, T. and Evans, O. (2020), "Finding common ground: The conception of community arts festivals as spaces for placemaking”, Health \& place, Vol. 61, pp.102254.

Chatterjee, H.J., Camic, P.M., Lockyer, B. and Thomson, L.J. (2018), "Non-clinical community interventions: a systematised review of social prescribing schemes", Arts \& Health, Vol. 10 No. 2, pp.97-123.

Daykin, N., Mansfield, L., Meads, C., Julier, G., Tomlinson, A., Payne, A., Grigsby Duffy, L., Lane, J., D’Innocenzo, G., Burnett, A. and Kay, T. (2018), “What works for wellbeing? 
A systematic review of wellbeing outcomes for music and singing in adults", Perspectives in Public Health, Vol. 138 No. 1, pp.39-46.

Daykin, N., Mansfield, L., Meads, C., Gray, K., Golding, A., Tomlinson, A. and Victor, C., (2020), "The role of social capital in participatory arts for wellbeing: findings from a qualitative systematic review", Arts \& Health, pp.1-24.

Denscombe, M. (2010), The good research guide. For small-scale social research projects, Open University Press, New York, USA.

Diener, E. (1984), Subjective well-being. Psychological Bulletin 95, pp. 542-75.

Driscoll, B. (2014), “The middlebrow pleasures of literary festivals", Driscoll, B. (Ed.s), The new literary middlebrow, Palgrave Macmillan UK, pp. 152-193.

Dougan Bowtell, K. (2012), "The effects of vinyasa flow yoga on contact improvisation in a festival setting Contact Festival Dartington”, paper presented at the Contact Festival Dartington, 28th July - 5th August, University College Falmouth, England, available at: http://eprints.lincoln.ac.uk/id/eprint/6463/ (accessed 09 December 2020).

Flatt, J.D., Liptak, A., Oakley, M.A., Gogan, J., Varner, T. and Lingler, J.H. (2015), "Subjective experiences of an art museum engagement activity for persons with earlystage Alzheimer's disease and their family caregivers", American Journal of Alzheimer's Disease \& Other Dementias, Vol. 30 No. 4, pp.380-389.

Garcia-Esquinas, E., Ortolá, R., Gine-Vazquez, I., Carnicero, J. A., Manas, A., Lara, E. and Rodriguez-Artalejo, F. (2021), "Changes in health behaviors, mental and physical health among older adults under severe lockdown restrictions during the COVID-19 pandemic in Spain", medRxiv. 
Global Sustainable

https://sustainabledevelopment.un.org/content/documents/24797GSDR_report_2019. pdf (accessed 28 June 2021).

Heldt, T. (2014), "Exploring the value of an event: comparing consumer surplus, willingness to pay and values of subjective wellbeing for the Peace \& Love music festival in Sweden", paper presented at the 23st Nordic symposium in Tourism and Hospitality Research, 2-4 October, Copenhagen, Denmark, available at: https://www.divaportal.org/smash/record.jsf?pid=diva2\%3A873932\&dswid=1941 $\quad$ (accessed $\quad 09$ December 2020).

Holloway, I., Brown, L., and Shipway, R. (2010), "Meaning not measurement: Using ethnography to bring a deeper understanding to the participant experience of festivals and events", International Journal of Event and Festival Management, Vol. 1 No. 1, pp. 74-85.

Huang, Y. C., Cheng, J. S., and Chang, L. L. (2019), "Understanding Leisure Trip Experience and Subjective Well-Being: an Illustration of Creative Travel Experience”, Applied Research in Quality of Life, Vol. 15, pp. 1-22.

Jepson, A. and Stadler, R. (2017), "Conceptualizing the Impact of Festival and Event Attendance upon Family Quality of Life (QOL)”, Event Management, Vol. 21 No. 1, pp. 47-60.

Jiménez-Pavón, D., Carbonell-Baeza, A. and Lavie, C.J. (2020), "Physical exercise as therapy to fight against the mental and physical consequences of COVID-19 quarantine: Special focus in older people”, Progress in cardiovascular diseases, Vol. 63 No. 3, pp.386-388.

Johanson, K. and Freeman, R. (2012), “The reader as audience: The appeal of the writers' festival to the contemporary audience", Continuum, Vol. 26 No. 2, pp.303-314. 
Lindert, J., Bain, P.A., Kubzansky, L.D. and Stein, C. (2015), "Well-being measurement and the WHO health policy Health 2010: systematic review of measurement scales", The European Journal of Public Health, Vol. 25 No. 4, pp.731-740.

Linton, M. J., Dieppe, P., \& Medina-Lara, A. (2016), "Review of 99 self-report measures for assessing well-being in adults: exploring dimensions of well-being and developments over time", BMJ open, Vol. 6 No. 7, pp. 1-16.

Kitchen, E., and Filep, S. (2019), "Rethinking the value of events for event attendees: Emerging themes from psychology", Armbrecht, J., Lundberg, E., and Andersson, TD. (Ed.s), A research agenda for event management, Edward Elgar Publishing, Cheltenham, pp. 6778.

Mackay, K. (2014), “Art as a connection to the divine in women's lives: cultural wellbeing through creative process", The International Journal of Social, Political and Community Agendas in The Arts, Vol. 8 No. 2.

Mellor, D., Hapidzal, F.M., Teh, K., Ganesan, R., Yeow, J., Latif, R.A. and Cummins, R. (2012), "Strong spiritual engagement and subjective well-being: A naturalistic investigation of the Thaipusam festival", Journal of Spirituality in Mental Health, Vol. 14 No. 3, pp.209-225.

Mirehie, M. and Gibson, H.J. (2020), “Women's participation in snow-sports and sense of wellbeing: a positive psychology approach”, Journal of Leisure Research, Vol. 51 No. 4, pp.1-19.

Nawijn, J., \& Filep, S. (2016), "Two directions for future tourist well-being research", Annals of Tourism Research, Vol. 61 No. C, pp. 221-223. 
Nieboer, A., Lindenberg, S., Boomsma, A., \& Bruggen, A. C. V. (2005), "Dimensions of wellbeing and their measurement: the SPF-IL scale", Social Indicators Research, Vol. 73 No. 3, pp. 313-353.

Ommundsen, W. (2009), "Literary Festivals and Cultural Consumption", Australian Literary Studies, Vol. 24 No. 1, pp. 19-34.

Quinn, N., Shulman, A., Knifton, L., \& Byrne, P. (2011), “The impact of a national mental health arts and film festival on stigma and recovery”, Acta Psychiatrica Scandinavica, Vol. 123 No. 1, pp. 71-81.

Relay of peace (2021) sdgs.un.org/partnerships/relay-peace (accessed 28 June 2021).

Rossetti, G. and Quinn, B. (2019), "Learning at Literary Festivals”, Jenkins, I. and Lund, K. A. (Ed.s.), Literary tourism: theories, practice and case studies, CABI, Wallingford, pp. 96-108.

Rossetti, G. and Quinn, B. (2021), "Understanding the cultural potential of rural festivals: A conceptual framework of cultural capital development”, Journal of Rural Studies.

Saragih, H.S. and Amelia, N. (2020), "Segmentation of music festival visitors by values of hedonia, life satisfaction and eudaimonia", International Journal of Event and Festival Management, Vol. 11 No. 4, pp. 53-472.

Soulodre, N.R. (2019), “Emerging Adult Women's Experiences of Music and Nature at a Music Festival”, doctoral dissertation, University of Saskatchewan, Canada.

Stevenson, N. (2020), “Developing academic wellbeing through writing retreats", Journal of Further and Higher Education, pp.1-13. 
Stevinson, C. and Hickson, M. (2019), "Changes in physical activity, weight and wellbeing outcomes among attendees of a weekly mass participation event: a prospective 12month study", Journal of Public Health, Vol. 41 No. 4, pp. 807-814.

Tan, K.L., Sim, A.K., Chai, D. and Beck, L. (2020), "Participant well-being and local festivals: the case of the Miri country music festival, Malaysia", International Journal of Event and Festival Management, Vol. 11 No. 4, pp. 433-451.

Taylor, S. J., Bogdan, R., and DeVault, M. L. (2016), Introduction to qualitative research methods. A guidebook and resource, John Wiley \& Sons, Inc., Hoboken, New Jersey, USA.

The Sustainable Development Goals Report https://unstats.un.org/sdgs/report/2020/The-Sustainable-Development-Goals-Report2020.pdf (accessed 28 June 2021).

UN (2020a) https://www.un.org/sustainabledevelopment/health/ (accessed 17 December 2020).

UN (2020b) Good health and well-being. Why it matters. https://www.un.org/sustainabledevelopment/wp-content/uploads/2017/03/3_Why-ItMatters-2020.pdf (accessed 24 March 2021).

Vada, S., Prentice, C., Scott, N., and Hsiao, A. (2020), "Positive psychology and tourist wellbeing: A systematic literature review", Tourism Management Perspectives, Vol. 33, p. 100631.

Weber, M. (2018), Literary festivals and contemporary book culture, Palgrave Macmillan, Canberra, Australia. 
Weinberg, M.K. and Joseph, D. (2017), "If you're happy and you know it: Music engagement and subjective wellbeing”, Psychology of Music, Vol. 45 No. 2, pp. 257-267.

Yin, R. K. (2016), Qualitative research from start to finish, The Guilford Press, London, UK.

Yolal, M., Gursoy, D., Uysal, M., Kim, H.L. and Karacaoğlu, S. (2016), “Impacts of festivals and events on residents' well-being", Annals of tourism research, Vol. 61, pp. 1-18.

WHO (2020) Covid-19 Strategy Update https://www.who.int/docs/defaultsource/coronaviruse/covid-strategy-update-14april2020.pdf?sfvrsn=29da3ba0_19 (accessed 24 March 2021).

Wood, E. H., Jepson, A., and Stadler, R. (2018), “Understanding the Well-Being Potential of Participatory Arts Events for the Over 70s: A Conceptual Framework and Research Agenda”, Event Management, Vol. 22 No. 6, pp. 1083-1101.

Wood, C. (2019), "Festival visiting, voluntary risk and positive health", Annals of Tourism Research, Vol. 76, pp. 323-325. 